\title{
Easing the strain
}

HE CAPACITY OF HUMAN BEINGS not under military discipline to withstand danger and endure deprivation had been put to the test in the First World War. Governments could take some comfort from the remarkable results of that test. Yet there was at the same time a warning in the experience: the capacity had limits. When tested beyond those limits the result that could be expected was at best crippling apathy and defeatism, at worst revolution. In Britain, as shown by Stephen Taylor's views (discussed at the beginning of Chapter 4), this reality was well understood by those in charge of the nation's affairs and consequently, the understanding was translated into policies favouring the 'material factors' of morale. For certain groups, these amounted to real improvements on pre-war conditions; but in general they were implemented in the knowledge that, for the most part, they could only offer mitigation of the worsened conditions brought by war. Their object was to so manage the stresses of war on the home front that defeatism was banished, war-weariness was held in check and the productive effort was sustained.

\section{Protection}

Nothing was more fundamental to this outcome than protection from bombs; the pre-war ARP plans testified to recognition of this fact in governmental circles. The Blitz was the proving ground of those plans. And as we have seen, it revealed many defects both in the umbrella of protection and in the post-raid services that together the Government and the local authorities had put in place. Mindful of the possible consequences of neglecting to act, during the period of intensive bombing itself and in the following months, both took steps to remedy these defects. Even had the threat to 
morale not been so palpable, a strong stimulus to action came, in any case, from the prospect of political trouble. This spectre was raised by a vigorous campaign for better shelter provision in which the Communist Party played a prominent part. The problem as the Government saw it was complicated by the implications for morale of adopting solutions that departed from its considered policy of dispersal - for this was the thrust of the demands being made by the campaigners. There was a case for arguing, in the light of experience, that greater harm would be done to morale by resisting the demand for the building of large, deep shelters than by conceding it. Doing nothing was not an option, however, and the Government, to its credit, acted with dispatch. It instituted a review of shelter provision and set up a committee under Lord Horder to examine and report on shelter conditions. By the end of September 1940 improvements to shelter conditions were already taking place and decisions had been made to enhance protection.

The changes in shelter conditions aimed to tackle the misery and squalor caused by overcrowding and the unanticipated use of shelters as overnight accommodation. A green light was given to local authorities to incur expenditure to install lighting, seating and bunks in street shelters. For the larger public shelters - those holding over 500 people - they were additionally encouraged to appoint a fulltime paid warden, to introduce a ticket system for places, and to install first aid equipment, toilets, heating and catering facilities. Provision was to be made for both street shelters and public shelters to be regularly cleaned and inspected. This was quite an ambitious programme involving large inputs of labour and materials resources on which there were many other calls at this time. The Government hit on an ingenious way of maximizing the deployment of these limited resources: it divided the entire country into areas, according to the urgency of local shelter needs. Top priority was given to areas that had experienced heavy and repeated bombing and to areas of similar national importance that had so far escaped; a rather lower priority was accorded to large industrial areas of dense population, together with some areas in the south east, the south and the south west of the country, which were considered especially likely to be attacked; and a lower priority still was given to the rest of the country. In this way the people who were actually experiencing raids were the first to see the improvements. 
Nights spent in communal or public shelters became less of an ordeal. Squalor was greatly reduced, if not entirely banished - most did not get running water and WCs - and in many cases the shelter came to have an agreeable social atmosphere, with organized entertainments, discussions and even educational courses taking place. An observer approaching one of the improved large public shelters in the capital at night would typically hear the sound of music, laughter, applause and the rattling of teacups, and at the door his nostrils were likely to be assaulted less by the stench of sweat, urine and excrement, than the homely smells of soup or cocoa.

But important though such improvements were to people's sense of well-being, still more important was the extent of shelter provision and the effectiveness of the shelters against bombs. The Blitz showed that locally what had seemed a sufficiency sometimes turned out to be a shortfall, since many of the surface street shelters were failing to withstand bomb blast, let alone direct hits, and were consequently being under-used by shelterers. This simple fact had the effect of falsifying the calculations of the authorities as to the preparedness of their districts for air attack, and instead presented them with the problem of large numbers of people seeking unplanned places of cover like the Underground railway, railway arches and the cellars and basements of any large buildings. Since it was evident that many people seemed to feel safer in these self-chosen 'people's shelters', especially the Underground, it made sense to recognize the value of this to general morale and to endorse it. One of the first things the authorities did, therefore, was to regularize their use, establishing in them the same standard of conditions that was being created in the official shelters - toilets, bunks, first aid posts, and the like.

An urgent need was to put right the structural defects of the street shelters. It emerged that one of the reasons why some had collapsed merely from the impact of bomb blast was that they had been built with mortar 'stretched' with lime, and in some cases with sand and lime only. This was a consequence partly of costsaving by firms contracted to build the shelters, and partly of misleading Ministry of Home Security instructions to local authorities in April 1940, which led some borough engineers to believe that cement-less mortar had official approval. Another defect that had come alarmingly to light was that when a bomb caused the ground 
under or near a shelter to move, the concrete roofslab lifted from the walls and then crashed down on them. People who had survived such an experience from the inside were naturally unwilling to trust a street shelter in future. The Government's solutions were threefold: to close (and ultimately demolish) those shelters that could not be made safe; to strengthen those that had proved reasonably safe; to build more shelters of improved design.

As this programme moved ahead, other measures were taken to reinforce and extend shelter provision. Trench shelters were strengthened with precast concrete linings and basement shelters with extra strutting. Experience had shown that large, steel-framed buildings were very resistant to the effects of bombing and that shelters in their basements were very safe, provided measures were taken to protect them from blast. Although to do so did not really conform with the dispersal policy, since every basement shelter in a large building would bring hundreds of people together in one place, the Government gave the go-ahead to local councils to require the owners of industrial and commercial buildings to make their basements available as public shelters outside business hours. In London, by the middle of October 1940, 340 extra basement shelters sufficient for 65,000 people had been acquired. ${ }^{1}$

A yet more radical departure from the dispersal policy came with the Government's decision to look again at the issue of deep shelters. By October the public agitation for deep, bombproof shelters was getting support from many quarters, including the more moderate sections of the press. The controversy was itself becoming a potential threat to morale. Against this background the Cabinet quickly reached a decision: authorization was given for the boring of a new system of tunnels linked to the London Underground and for tunnel boring to be carried out in locations in the regions where features like caves and quarries permitted it to be done without enormous cost. The London scheme alone created 64,000 extra bombproof places for shelterers and tunnelling schemes went rapidly ahead elsewhere: in Nottingham some of the many caves in the city were improved and strengthened; in the chalk of the North Downs in Surrey the county council bored five tunnels; in Birkenhead a shelter tunnel was made at the old Tranmere Quarry; in Portsmouth an old tunnel at Egg Buckland was converted and a new tunnel was made in Portsdown Hill. 
This did not amount to an abandonment of the dispersal policy, for there was no decision to build deep shelters everywhere, but it was, like the earlier decision to give way on the use of Underground stations as shelters, clear evidence of a government anxious to do whatever seemed best for the preservation of civilian morale. It was a decision, moreover, that was virtually dictated by the politics of the moment: nothing less than the public's confidence in the Government seemed to be at stake. When the first surveys of public opinion - as distinct from the views of those claiming to represent it - were made in late November 1940, confirmation came of the wisdom of the concessions made towards deep shelter provision. In a nationwide survey, Mass-Observation asked: 'Do you think the Government has been wise or unwise in favouring the building of surface shelters rather than underground shelters?' While 14 per cent said they were wise, 71 percent said unwise. This confirmed a Gallup poll in London and the South East, in which 74 per cent said 'unwise'. When Mass-Observation asked about surface shelters, 67 per cent gave unfavourable answers and only 19 per cent gave favourable answers. ${ }^{2}$ Public distrust of surface street shelters persisted even after the official attempts to rehabilitate them by reinforcement and design changes. Mass-Observation found, in a survey of August 1941, that for every one person in favour of them three were still critical. ${ }^{3}$ In other words, rehabilitation alone would not have been enough to allay public fear of under-protection.

Once it had defused the deep shelter issue, the Government was able to consolidate an aspect of its policy that was quintessentially dispersive - the production and distribution of more domestic shelters. In the five months to the end of March 1941 another 184,000 Anderson shelters were made, giving home protection to about $1,100,000$ people; and in the year to December 1941, 1,080,000 of the newly designed indoor domestic shelter, the 'Morrison', were manufactured, giving protection to a further 4,320,000 people. Cramped though it undoubtedly was if used by more than two people at once, the great virtue of the 'Morrison' was that it enabled users to bed down for the night within the relative comfort of their own home.

While it is true that the greater part of this ambitious programme of protection was yet to be realized by the time the Big Blitz ended in May 1941, there is no doubt that as a potential source of low 
morale, the problem of inadequate protection from bombing was solved. If anything, the country came to seem overprovided, for the bombing was never again as bad as it had been in the nine months from September 1940. In another sense, too, there was overprovision. A survey conducted during the Blitz in early November 1940 revealed that only 40 per cent of the capital's population actually used shelters during air raids. ${ }^{4}$ Although more probably did so in September and October, when the bombing was worse, these figures are very revealing. Put another way, 60 per cent of people were so unalarmed that they chose to keep to their beds, at most moving those beds to the ground floor. The gap that campaigners pointed to between the number of shelter places and the population of the city was a purely paper affair: in reality, there was, and with some few local exceptions, like West Ham - had been from the start, enough shelter for those who wanted and would actually use it. ${ }^{5}$ While bombs were falling, shelters might be half-empty. It was a paradox, but for morale's sake it had to be. The true value of the enhanced physical protection was measured not so much by how much it was actually used but by the feeling of security that its presence imparted.

In the matter of shelters the Government continued to have 'Be Prepared' as its motto. Intelligence about Germany's V-weapon programme led to a decision to manufacture another 100,000 Morrison shelters and to move the national reserves of this type of shelter near to London, the presumed target. There were, as it happened, sufficient of these for distribution to meet demand when the conventional bombing campaign known as the Little Blitz unexpectedly erupted onto the capital early in January 1944 and carried on for three months. The stocks of Morrisons held in London Region during these raids never fell below 27,000. When the $\mathrm{V}$-weapon raids finally came in June 1944, people did start sleeping again in the Underground and in the public shelters, but the demand was not sufficient to cause the Government to open up the new Underground deep shelters, which it had by this time designated as a reserve for operational purposes. ${ }^{6}$

In retrospect, the start of the bombing was a difficult time for the Government in maintaining public confidence in its policy of protection. But on the matter of shelters it recovered the position well. By a judicious mixture of concession and spending it was able 
to satisfy the popular demand for subterranean shelter without completely abandoning the policy of dispersal, which it continued to believe better for morale. In consequence there was never again the morale-threatening clamour that had momentarily unnerved officials at the start of the Blitz. People felt as safe as it was possible to be in the circumstances of modern war and came to take for granted the protection that the authorities had provided.

The other main way of providing protection - evacuation - was tried, as we have seen, with equivocal results at the start of the war. Evacuation seemed to many people not such a bad idea, after all, once they had experienced the realities of bombing. The Government exploited this sentiment by renewing its propaganda campaign to get people in the bouches inutiles category to leave the danger zones and by improving the financial incentives for them to do so. In fact, the prototype of this initiative was already in operation as part of the scheme to reduce the civilian population in the vulnerable coastal areas of the east and south - vulnerable, that is, not so much to bombing but to invasion. After the fall of France, the Government announced the 'Assisted Private Evacuation Scheme'. This offered free travel vouchers for mothers with children under five who had made their own arrangements for a billet in a safe area, and extended billeting allowances to the householders who received them, even where they were relatives or friends. While this scheme originated in the army's wish to rid the security zone of as many civilians as possible, its appeal for the Government lay partly in giving it a practical way of responding to popular fear of invasion, which was potentially damaging for morale. Under the scheme, 56,000 accompanied children and 49,000 unaccompanied children left the coastal belt and were billeted in reception areas. ${ }^{7}$ When bombing of the capital began in earnest in early September the Government's initial response was to use the successful assisted evacuation arrangement. There was one small departure from this policy, which came as a result of a near panic demand by councillors and officials in West Ham for the wholesale evacuation of the borough, or at the very least, the worst-hit district of Silvertown. The Minister of Health, Malcolm Macdonald, visited the area on 11 September and took what Titmuss described as 'a brave and imaginative decision': transport would be provided the next day to evacuate anyone who wanted to leave Silvertown for billets in safer 
parts of London. ${ }^{8}$ On the following day about 2,900 people, a small fraction of the population, presented themselves for removal. The Government's willingness to move with the tide of feeling was not only brave and imaginative; it was also shrewd, politically, and because it quickly told them that morale was better than the alarmists were saying. Panic and hysteria could be discounted; most people, even in this terrible cauldron of dockland, wanted to stand their ground and fight.

But as the murderous weeks passed the cry for evacuation again went up and the Government knew it had to do more. On 22 September, therefore, it offered an organized evacuation for homeless mothers and their children, limiting the scheme to the worst-hit boroughs of east London. After the Silvertown experience, it was not surprised that the take-up was small - only about 2,600 in the last week of the month. It seemed that there was no danger of the scheme cutting across the coastal evacuation process by using up all the available billeting places, so the Government extended it to all mothers and children in the London boroughs and even to several areas that were technically outside the county of London. This produced a sizeable, although manageable, evacuation of about 89,000 in October, followed by 11,200 in November and just 1,300 in December. ${ }^{9}$ Once again, as with the question of shelters, there was a gap between the noise that the media and other groups were making and what the people actually wanted. When it came to it, the desire to stay close to home was for most people stronger than the wish to escape the horrors of daily life on the front line. While it probably helped to have the lifeline there to be grasped, it seemed that morale was less fragile than it had at first appeared to be. Titmuss has argued that the morale of people who chose to risk the bombs in order to keep the family together may well have been better than those who opted for a safe but separated existence, and that this was particularly the case among the poorer sections of the population, 'for among those with little property and social esteem, family members and family relationships are extremely important. With his own family the individual is, and what is more feels like, "somebody". 10

For those who stayed, the Government - or rather the army and the RAF - found an easy, though expensive, way of keeping up spirits: hitting back at the enemy. We have already noted how the 
raids on Germany were given maximum publicity to this end, but this was something rather remote from people's own lives and in any case had to be taken on trust. For the beleaguered people of the capital during the sustained bombing of 1940-41 there was the much more tangible - or rather, audible - evidence of strikes at the enemy's bombers, using anti-aircraft guns and nightfighter planes. There was naturally nothing the authorities could do about the noise of bombs; but the colossal racket created by the anti-aircraft barrage was a conscious choice. The effectiveness of the guns in actually bringing down enemy planes was slight but it was judged worth doing because the noise countered the impression fearful civilians might otherwise have that nothing was being done to parry the attack. The Ministry of Home Security had in fact noticed and recorded that the people's morale during an attack was 'noticeably improved by the effectiveness and ... the visibility and the audibility of both the active and the passive defences'. ${ }^{11}$ In the first few days (7-10 September) London's AA batteries were little used because of the risk of shooting down the RAF's nightfighters. Since the latters' operations were not very obvious to the public, the decision was made to withdraw them for a while to enable the AA batteries to treat all planes as targets. On 11 September the head of Anti-Aircraft Command, General Sir Frederick Pile, had positioned 199 AA guns in London. That night (and throughout the Blitz) they set up a huge barrage that forced the raiders to fly higher and to avoid the inner artillery zone. Few actual 'hits' were made and the enemy was clearly not being prevented from continuing to drop many bombs. But this was not really the point of the exercise: in strictly military terms the advantage, at least at this stage in the development of interception methods, lay with the attacker. The real value - and purpose - of the AA barrage was its psychological effect on the civilian population. 'It is difficult to express how enchanting the roar of these big guns is to the dwellers of London', recorded the US military attaché, General Lee, when some large naval guns were added to the barrage. ${ }^{12}$ The noise of this barrage made sleep difficult for millions, of course, thereby adding to the problem of fatigue, and anyone outside ran the risk of being hit by falling shell fragments. But the compensation was that people got relief from the yet worse problem of feeling helpless, of being sitting targets without the means to hit back. The Ministry of 
Information's Home Intelligence Division reported that the night of 11 September was a great stimulus to civilian morale. ${ }^{13}$ MassObservation recorded some reactions a week after the new barrage started, confirming the Government's judgement that the barrage, if militarily ineffectual, was worth its weight in gold as a booster of morale: 'I love the sound of the guns!'; 'I must say that though the noise was awful last night, we were all relieved to hear it. The louder it was, the greater confidence we had'; 'You can't sleep with the guns, but it's a good sound.' ${ }^{14}$ The effect was purely local, of course, and could not be repeated on anything like the same scale in every place where there was serial bombing. But this was, after all, the time when London was 'taking it' and the morale of the capital's large population was a matter of some importance.

The use of nightfighters did not stop entirely. In time, it was possible, through phasing and zoning, to have the AA barrage and nightfighters operating more or less simultaneously. Methods of interception were developed and radar was introduced for the AA guns and by March both planes and guns were getting more 'hits'. This expertise, coming towards the end of the Big Blitz, was not wasted. When the $\mathrm{V}$-weapons began, the combined AA barrage and nightfighter operation was reactivated, AA units being brought in from all over the country; for by this time, the Government was worried that after five years of war the civilian population was more vulnerable to the strain of living with bombing than in 1940$41 .^{15}$ Once more, then, visible and audible retaliation was called in for what was believed, by then, to be its proved value for morale.

Whether the desired effect of all this effort was achieved is difficult to say. The best indication that the upgrading of ARP helped civilian morale is that the bitter accusations of official negligence that were heard in London in the first weeks of the Big Blitz and elsewhere as the bombing campaign widened to the provinces, were never repeated in the remaining four years of the war; people seemed satisfied that what could be done was done and they felt better for it.

\section{Food}

Only a small minority of the population was actually bombed; and of these a smaller number still was rendered homeless by bombing. Food, however, involved everybody. Here, the spectre of 1914-18 
was never far from the minds of ministers. It was held to be imperative for the morale of the nation that its will to work for victory was not undermined by having too little to eat, whether through shortage of food supplies or their high cost. Feeding the nation - a nation mobilized for total war - was deemed as important as supplying the armed forces with the weapons of war. At the most basic level, then, the problem was to ensure that there was enough food available at affordable prices for the normal calorific needs of the average person to be maintained. Maintaining the supply was to be achieved by rationalizing total imports, increasing home food production and controlling food distribution. ${ }^{16}$

Getting right the arithmetic of total food available divided by the number of mouths to be fed was just the start of the task, however. Just as important was to make sure that, when margins were tight, some did not - through wealth or influence - get more than they needed. For if normal market forces were allowed to operate, this was inevitably what would happen. Attached though they mostly were to the virtues of the free market, ministers and officials understood that the exigencies of total war would require compromises. From this basic assumption the scheme for food rationing and the control of food prices was devised. There would be enough of most sorts of food, but not enough for everyone to have as much as they might like of any one sort. ${ }^{17}$ The scheme would be calculated expressly to prevent anyone from feeling that others were getting more because they were richer and could simply pay for it. In short, the scheme's watchword was fairness, or 'fair shares for all', as the official slogan had it.

Chapter 2 demonstrated how the Government was reluctant to depart from 'natural' economic laws even though the inflationary and inequitable consequences of clinging to them soon became apparent, and how this, by November 1939, had been needlessly allowed to become a source of public discontent. But once the principles of food control, food rationing and food subsidy had been conceded, there was no going back. Government management of the nation's food became a significant way of exerting influence on the public state of mind, and the man at the heart of food policy, the Minister of Food, Lord Woolton, became a key figure in maintaining the people's morale. It should be stressed that, sympathetic and well-liked though he was, Woolton, like most of his colleagues, 
did not act from considerations of social justice when he promoted the idea of 'fair shares for all'. His own philosophy tended more towards the virtues of self-help and the nightwatchman state. But his political instinct told him that in total war these principles would spell disaster for the government that insisted on them. The simple facts were that in working-class families about three-fifths of income was spent on food and that rapid, uncontrolled increases in food prices would give rise to distress, quickly followed by political trouble in the form of demonstrations, strikes, and trade union demands for wage increases to match the price rises. A spiral of inflation would be created that could derail the entire war economy. Food, in short, was political dynamite; Woolton's task was to so manage the consumption of food that its explosive potential was never released. ${ }^{18}$

An early indication of official recognition of the political importance of food was discernible even before Woolton's arrival at the Ministry after Chamberlain's reshuffle of early April 1940. The Ministry could not control world prices, of course, and food items in the Ministry of Labour cost-of-living index had risen by sixteen points in the two months to the end of October 1939. This was alarming enough in its political implications; but the rise would have been bigger still had not the Ministry of Food absorbed heavy losses on its trading account - running at the rate of $£ 1 \mathrm{~m}$ a week by mid-December. ${ }^{19}$ Without this hidden subsidy the retail price of a standard loaf of bread, for example, would have risen another 12 per cent. For want of a better alternative, the Government allowed the Ministry to continue to absorb the inflation in the prices of imported foods. By January 1940, it had decided to carry on fixing food prices and was coming round to the view that the practice should be extended to all imported commodities included in the index. Its rationale was that it was in the long term cheaper to subsidize staple items of consumption than to allow price rises that would stimulate demands from organized labour for wage increases and which, moreover, would produce an atmosphere of conflict that was damaging to the war effort in general.

The case of milk, however, showed that there were some voices within government that did not share this purely instrumental attitude to food policy. When in December 1939 it looked as though the Ministry of Food was about to announce a flat increase in the 
price of milk, officials in the Ministry of Health lobbied for special measures to be taken to ensure that the beneficiaries of the pre-war cheap milk schemes, especially mothers, and children under five, should not suffer as a result. Their worry was that the price would be a deterrent and that consumption would fall, with consequent loss of benefit to the health of the poor. They argued for a national scheme that would provide milk at twopence a pint to all 'priority classes', without a means test. This was opposed by the Treasury, but the matter was still unresolved by the time the coalition government was formed. Woolton, the new Minister of Food, was persuaded that some sort of national scheme was necessary to offset the imminent price rises. In the meantime he obtained a temporary continuation of the subsidy on all milk prices until July. The next step was a momentous one: Woolton got the Food Policy Committee to approve the inclusion in the scheme of the right to free milk for very poor mothers and children. This was more than a mere food regulation; whatever its intention, in effect it was a piece of social reform, one that became a precedent for the Welfare Foods Scheme (which began in December 1941) whereby free or cheap cod liver oil, orange juice and National Milk-Cocoa were made available to vulnerable groups such as expectant and nursing mothers, children, adolescents and invalids.

But on the general question of food subsidies, the Government was still strictly instrumental in its attitude. The Cabinet resolution of August 1940 set out the basis for the policy that was to be adhered to, with little adjustment, for the remainder of the war: 'the prices of essential foods should be kept down by subsidy in order to secure cheap food, to restrain a rise in the cost-of-living index figure, and to prevent wages rising ... luxury foods shall be allowed to find their own price level'. ${ }^{20}$ This did not mean no price rises at all - the cost-of-living increased about 30 per cent during the war but most of the rise occurred in the first two years, prices remaining stable thereafter. Subsidies on food prevented the retail price of basic foods from rising further. Without the subsidy, bread would have cost 45 per cent more, meat 33 per cent more, milk 11 per cent more. $^{21}$

The adjustments that were made to the food rationing scheme after its introduction on 8 January 1940 reflected the basic thinking that underlay it from the start. Items of basic foods were added 
to the list only when the supply situation worsened to the point where an unacceptably large increase in price threatened. Thus meat was rationed from 11 March 1940 and tea from 9 July. Some adjustments looked like concessions to humanity - the extra cheese ration allowed to certain manual workers, like miners and farm labourers, who had no access to canteens, for instance - but in reality, behind every such adjustment was the principle that where neglect of grievance could lower morale in key sectors of the war economy, then the prudential course was to remedy the grievance.

Two adjustments, however, responded to grievances that were more generally felt: those relating to unrationed foods and to restaurant meals. Until November 1941, a wide range of food - mostly tinned or dried - was unrationed. In theory, when prices were subject to controls, everyone had an equal chance, subject to availability, of obtaining these items. In practice, the better-off had an advantage because they could use their greater disposable income to stock up on these storable foods whenever they appeared in the shops, if necessary going from shop to shop to do so. Some shopkeepers limited the amounts each customer might buy at once but others were willing to sell in bulk, or even to put the sought-for items 'under the counter', for sale at inflated prices. Naturally, in this situation there was much potential for social discord. To prevent this, a points rationing system was devised which gave unrationed foods a points rating and allowed every person sixteen non-specific points every four weeks, to be used only for these items, according to preference. An attraction of the system for the Government was that it was flexible: the points rating of items could be increased or reduced according to their fluctuating availability. The system was introduced piecemeal, beginning with certain tinned foods - meat, fish and vegetables in November and then by stages over the year to December 1942, to rice, sago, tapioca; dried pulses and fruit; tinned tomatoes, peas and fruit; cereals, condensed milk, treacle, syrup, biscuits, and oats. Since the sixteen points were valid for four weeks only, there could be no question of accumulation. This went a long way towards solving the problem of the customer with the bottomless purse hogging the supplies of tinned pilchards, or whatever unrationed item happened to become available. It also gave people some choice - to indulge in a 'luxury' or get more of an item whose supply fluctuated. 
The rich could continue to eat well, however, by taking couponfree meals in restaurants. Although the scale of this scarcely mattered in terms of the national food strategy, luxury feeding at a time of general austerity was difficult to defend and it was certainly disproportionately damaging to the idea of equal shares and everyone pulling together. Home Intelligence reported in March 1942 that there was growing evidence of a perception among certain sections of the public of 'inequality of sacrifice', a perception created in the first instance by the resort of the rich to expensive restaurants. ${ }^{22}$

After considering and rejecting as administratively too complex or expensive various ideas for bringing restaurant meals within the framework of rationing, the Government settled for the simple, if flawed, device of a maximum charge. From mid-1942 a restaurant meal might cost no more than five shillings (the equivalent of $25 \mathrm{p}$ ). ${ }^{23}$ In theory this made it unprofitable for restaurateurs to buy on the black market knowing they could recoup their costs in the cover price. However, while most probably accepted the new regime, some luxury establishments were able to get round the intention of the regulation by adding to the five shillings an artificially high charge for the 'extras' - the orchestra, the dancing, the cabaret, and the like. The Government had done its best in what was admittedly an administratively difficult matter. Complaints about people eating out to dodge rationing did disappear from the soundings of opinion, at least, so it might reasonably be inferred that the matter's morale-eroding potential was checked.

A contributory factor in this was undoubtedly the appearance of one of Woolton's most inspired innovations: British Restaurants. Canteen-like food in canteen-like conditions at canteen-like prices was what these establishments offered. This was off-ration eating out, too, but at a price ordinary people could afford. They were an immense success, catering to capacity wherever they opened. It would certainly have been an unpopular move to include these meals in some sort of points or tokens scheme, which in fairness they would have to have been were this imposed on restaurants catering to the well-off. ${ }^{24}$ As it was, British Restaurants, by giving some relief from the constraints imposed by the basic rations, were a powerful force for public contentment.

Other initiatives by Woolton showed an equally sure touch in winning popular confidence and approval: the setting up of the 
Queen's Messengers - volunteers using 144 vehicles to take in food relief after air raids; the 'Food Trains', which ran in the Underground from 7.00-9.00 a.m. and 5.00-7.00 p.m. to feed shelterers; the 'Pies Scheme', whereby WVS teams took pies out to farm workers on certain days of the week; the extra cheese ration for agricultural workers; the creation of local Food Officers in every village, with stocks to supply local people in the event of a serious interruption of supply; the placing of soldiers on administrative duties in Britain onto the same rations as civilians; the programme of vitamins and extra foods for babies, children and pregnant women. Even the US Army was persuaded to cooperate. The relatively higher standard of food American servicemen enjoyed on their bases was naturally a cause of some envy among native inhabitants when the - often exaggerated - details got out. It was therefore a shrewd move to get the European Theater of Operations, US Army to agree that the troops' bread would be made not with specially imported North American wheat but with the basic ingredient of the unloved British National Loaf - National Wheatmeal Flour. ${ }^{25}$ All even, then - at least as far as the staff of life was concerned.

When Mass-Observation reported on 'Food Tensions' in March 1942, it concluded that the Government's food policy was working. Among women questioned, there was less tension than there had been over the inconveniences and restriction of choice. A figure of 77 per cent felt the situation was better than they had expected and felt they were managing well in the circumstances. ${ }^{26}$ In his analysis of the food situation a month later, Tom Harrisson thought people were more satisfied because they were more convinced that food was being fairly distributed; the system of points rationing seemed fair; many of the causes of friction, such as queuing, had been removed or eased; and Woolton was thought to be sympathetic and doing a good job - a verdict confirmed in a Gallup poll in May, in which 79 per cent thought he was doing a good job as opposed to only 12 per cent who thought not. ${ }^{27}$

They were not alone in thinking well of Woolton. When the extra foods and vitamins scheme was established, the Ministry of Food received many grateful letters from recipients and from serving soldiers, thanking the Ministry for taking care of their dependants. ${ }^{28}$ On the occasion of his appointment in November 1943 to the new post of Minister of Reconstruction, the Montreal Gazette wrote: 
'the famous British morale can be credited as much to Lord Woolton as to any individual'. ${ }^{29}$ For the Government, the Food brief was crucial in the maintenance of civilian morale and Woolton more than fulfilled his mission. It has to be admitted that he was also a skilful self-publicist; but it was all for the cause and no one disputes that his reputation was deserved. His 'Fair Shares for All' slogan had just the right populist appeal in a 'people's war'. It was never literally achieved, but then, no one realistically imagined that it could be. The grosser disparities were removed and for most people this was enough. A significant minority of the population actually fed better - in terms of both quantity and variety - than before the war. Full employment and increased average real income were the real basis for this, but Woolton's wartime food regime was also seen as part of it. Above all, like the good businessman he was, Woolton turned a situation of deficit into one of healthy profit: instead of being a threat to morale, the food issue became - for a sizeable proportion of the nation, at least - a significant factor of good morale.

\section{The cost of living}

Food policy was part of a wider policy to hold down inflation. Inflation was recognized as an inevitable concomitant of war, but the Government took the view that a determined and imaginative policy could prevent it from getting out of control. Rampant inflation would have spelt economic trouble for an economy that was in any case having to adjust to extraordinary circumstances, and it was also guaranteed to stimulate social, and possibly political, unrest. Rejecting a policy of wage controls as likely to create conflict between it and the workers, the Government instead adopted measures designed to control the cost of living and thereby to check the demand for inflationary wage increases. ${ }^{30}$

One of the biggest problems was unfortunately one that the Government was powerless to resolve: the price of imported goods. These increased sharply - those, at least, from sources other than the Dominions. The Government gave subsidies to shipping and transport and it rationalized imports to eliminate inessential items; this helped to limit the inflationary effect of the increasing cost of imports, but it nonetheless remained something that simply had to be lived with. 
The demand side of inflation could be tackled more easily. The inflationary gap between supply and demand that opened up as war production expanded and consumer goods production fell was addressed by fiscal measures: income tax went up from 9 to 50 per cent, personal allowances were reduced, and purchase tax was increased from 60 to 100 per cent. Any remaining excess demand was absorbed by forced savings, war bonds at attractive rates and control of bank lending. ${ }^{31}$ Rationing, too, by controlling demand, played its part in the war against inflation. Finally, prices were held down by subsidies on key items in the cost-of-living index and by the imposition of price controls.

Through this battery of interventions the cost of living was stabilized. Although retail prices generally continued to rise - by 42 per cent from the start of the war to the end of 1943, according to one estimate - the cost-of-living index scarcely fluctuated at all after April 1941 and the overall increase at the war's end, largely the result of the inflation of 1939-41, was about 30 per cent. ${ }^{32}$ At that point about 95 per cent of all household expenditure was on pricecontrolled goods.

Since average wage rates rose 30 per cent by 1942 and 50 per cent by 1945 , the real income of the average family was actually higher during most of the war than before it. ${ }^{33}$ If average earnings rather than average wages are considered, the improvement was greater still: the average weekly male earnings in industry (the best case) increased by 76 per cent, giving a rise in real income of 46 per cent. ${ }^{34}$ Average figures, of course, conceal individual situations. But the Government was ready to respond to these when unacceptable inequality was demonstrated, as in the 1940 Old Age and Widows' Pension Act, which greatly increased the value of pensions and empowered the Assistance Board to pay supplementary pensions when need was shown (this immediately tripled the number of pensioners receiving supplementary allowances, bringing the total to over one million); or when in 1942 and again in 1944 the allowances for private soldiers' wives were increased. ${ }^{35}$ Accepting that there were individual cases of hardship, the effect of the changes in prices and wages during the war was not damaging to the living standards of the average family. There were naturally certain frustrations built into a situation in which enhanced purchasing power coincided with reduced choice of things to be purchased, but this 
was for many families more than compensated by the possession of a margin of financial manoeuvre. The disappearance of the hidden undernourishment of the 1930s was just one manifestation of this. Insofar as discontent fuelled by perceptions of falling living standards was potentially a threat to civilian morale, Government action achieved its purpose. The soundings of public opinion do show continuing grumbles about consumption-related matters, such as shortages and queuing, but the real complaints about prices and the difficulty of making ends meet that marked such surveys in the first eighteen months of the war, fall out of the picture thereafter. All rationing - of food, clothes and fuel - restricted choice; but when asked, the majority approved because in a free-for-all, only the rich could do well, at the expense of others. Most of the informal record of the war years - letters, diaries, memoirs - was made by people who belonged to the middle classes, people, that is, whose lifestyle was usually adversely affected by the rather basic consumption standards the war imposed. But for the majority, these standards did not constitute a worsening, and for a significant section among that majority, they were actually an improvement on what they were accustomed to before the war. In the battle for civilian morale, the Government knew it was the majority that mattered. If the better-off felt the pinch more, this was judged a small and acceptable price to pay to win the battle. ${ }^{36}$ One member of the middle classes, the journalist J. L. Hodson, recorded with approval the remarks of 'a young Radical friend' on the spin-off benefits of the war:

We've given coalminers a minimum of five pounds a week; we've opened up shipyards that had been derelict; we've made wastelands fruitful, and cultivated millions of acres that lay idle ... Our heavy taxation and our rationing of foods has, willy-nilly, achieved some levelling up of the nation; fewer folk have gone hungry and fewer have gorged themselves; the poor have been a trifle better off and the rich a little less rich. $^{37}$

Allusion has already been made to the role of wages in the state of civilian morale. The fact that wages kept ahead of prices was not entirely the product of the increase of the demand for labour over the supply; it was also a result of a deliberate policy by the Ministry of Labour and National Service. When Ernest Bevin accepted the post of Minister in Churchill's coalition government, he did so on 
condition that he be allowed to take measures to improve the wages and conditions of the workers from whom he was going to demand extraordinary productive effort. A rise in the working-class standard of living seemed to him both morally justified and a practical proposition, even in the midst of a war for survival. The practical side of the argument won the day, for who could doubt the logic of the productive payoff of a well-motivated workforce? Bevin was therefore permitted to ride the unsaddled horse of wage inflation, which he proceeded to do with great skill, allowing wages to catch up and overtake the price rises he inherited and then, by carrot and stick, holding them at a level that did not damage the overall financial strategy. In return for controls over prices and profits, and comprehensive regulations for industry as a whole, Bevin was able to get the trade unions to accept a policy that gave higher rewards for workers but within a framework of wage restraint. His special skill lay in getting employers to support this, too. ${ }^{38}$ All the troubles of wartime labour pale into insignificance besides this achievement. Like Woolton, by his actions rather than his words, Bevin had far more friends than enemies among the mass of the people; and like Woolton, he succeeded in winning their cooperation.

\section{Working conditions}

Bevin was the prime mover in another area of government action that had morale implications: industrial welfare. This was a neglected aspect of the industrial scene; in fact after the start of the war, because of problems like transport, lodging and feeding, the welfare of workers was deteriorating. The arrival of Bevin at the Ministry of Labour turned the tide. He raised the profile of welfare as soon as he was in post, insisting first that the Factory Inspectorate be detached from the Home Office and incorporated into the Ministry of Labour; and then in July 1940 issuing an order that empowered factory inspectors to compel businesses employing more than 250 people to appoint welfare officers, backing this up with subsidized training courses for welfare officers. In 1941 the Ministry guided employers to match the increase in the proportion of women workers by appointing more women welfare and personnel officers.

Under Bevin's proactive policies the working environment of factories was improved in all sorts of practical ways. Factory medical 
services, which varied greatly between firms, were generally improved by Ministry persuasion, but it was made clear to employers that the inspectors had power to direct them to appoint such a number of full- or part-time doctors as seemed needed, given the number of employees. Factory doctors were given the role of consultants and examiners on the matter of an individual's fitness to carry out a specific job. At the time of the order, July 1940, there were only thirty full-time factory doctors in the country; by 1944 there had been a six-fold increase, with the number of part-time doctors going up from 50 to 890 . Factory nurses, meanwhile, increased from 1,500 in 1939 to 4,000 by 1942, and to 8,000 by $1943 .{ }^{39}$ Bevin made it clear that these changes were more than a wartime expedient: he intended them to become permanent. In November 1940 the Factories (Canteens) Order was made, under which factory inspectors could direct employers on munitions or other government contracts, who employed more than 250 workers, to provide canteens for them. The pill was sweetened by an accompanying provision for up to 60 per cent of the cost to be met by the Government. At the end of 1941 the same help was offered to smaller enterprises outside the scope of the Order. By 1944 there were 5,000 canteens operating in the larger firms - an increase of 300 per cent. Canteens in smaller enterprises increased from 1,400 in 1941 to 6,800 in 1945 . Quality trailed behind quantity for a while; then, after complaints about poor canteen food, an Order of October 1943 imposed tighter control of catering licences and gave factory inspectors the power to force employers to remedy any defects revealed by inspections. ${ }^{40}$ The problems of long, crowded and expensive journeys to work were tackled in various ways. A massive hostel-building programme was undertaken - enough for 65,000 workers - but they were never as attractive as living at home, despite the journey problems. So the Government worked with the grain of popular preference and produced the Assisted Travel Scheme, which subsidized travel costs of over three shillings (15p) a week and modified the detailed working of transport systems to reduce the frustrations of travelling for workers. ${ }^{41}$ Meanwhile, in the special conditions of the Royal Ordnance Factories, the Government set an example by putting its own house, as it were, in order. Reports by the Welfare Advisory Panel highlighted persistent problems to be remedied: bad ventilation and lighting; inadequate 
facilities for drying clothes in wet weather; unsupervised restrooms; a shortage of seats for women workers; dirty and slippery shopfloors; unhygienic canteens; fumes from explosives. Within a year, all ROFs had shown improvement in these areas, including effective measures to reduce the incidence of dermatitis and toxic jaundice. ${ }^{42}$

By the end of the war, the welfare of workers had taken a sizeable leap forward. In other ways, wartime work remained a stressful affair; but the long hours, the shiftwork and the difficult journeys to and from work were to some degree compensated by the tangible effects of the new resources that were introduced and of the official pressure on employers to look after their workers better.

\section{Health}

It has often been remarked that the health of the nation was in general better in the war years than it had ever been - a paradox, given the facts of bombing, shortages, rationing and mental and physical strain. While to some degree this was an unanticipated development, there is no doubt that it was also the product of measures calculated to achieve this outcome. More accurately, the measures were designed to prevent anticipated deterioration of health; the fact that - from 1942, at least - the usual indices of health showed an improvement, was a welcome bonus. Already in September 1941, Lord Woolton was triumphantly proclaiming that the nation had 'never been in better health for years'. Woolton, of course, had reason to think he himself had had a hand in this; 'it is my responsibility', he said, 'to secure that so far as food is concerned, the nation is kept fit and well'. ${ }^{43}$ Nutrition was at the heart of his rationing system. It did not matter much that the massive campaign to persuade people to eat more healthily largely fell on deaf ears; the basic facts of rationing and food management automatically ensured this outcome. The National Wheatmeal Loaf, for instance, was nutritionally far superior to the white bread that most people ate before the war; and if people had less meat and filled up on vegetables and grain products, this incidentally gave a better nutritional balance to their diet. $^{44}$ As far as the improvements in child health are concerned, among the factors involved though no direct cause and effect relationship can be demonstrated - few doubt that the welfare foods programme was significant. But 
the fact that death rates among the elderly declined in the war years reminds us that the more general improvement in health did not depend on such targeted provision. Insofar as this is explained by government interventions, the afore-mentioned policies of price control, food subsidies and 'fair shares for all' were the likely agents.

Mass-Observation tried in December 1940 to discover what the main influences were on people's state of mind, that is, what things kept up their spirits and what things depressed them. It did this by asking its national panel of voluntary observers to observe themselves, keeping a daily chart on the things that affected how they felt. The initial findings were equivocal. But when the factors were rated according to the number of references made to each without regard to its supposed effect, the resulting table put 'Health' first, well clear of 'Work', 'Weather', 'War News' and 'Friends', which followed. ${ }^{45}$ Tom Harrisson later conceded that this was a rather rough measure. ${ }^{46}$ But it showed that a 'non-war-related' factor was important to how people felt, even at this very bleak and dangerous time in the war. In aiming to prevent health standards from deteriorating under the impact of war, then, the Government had stumbled on what appeared, in the event, to be a significant factor in civilian morale. People may not have made any connection between their health and the policies of the Government (although the more thoughtful might well have done so); but the important thing - if the statistics mean anything - was that people must have felt their general health was at least not worsened by the war, which was undoubtedly more than they had expected. An inquiry into public attitudes to health in July and August 1942, based on a sample of 1,795 people, found that 53 per cent thought their health was the same as before the war, 10 per cent thought their health had improved, 37 per cent that it was worse or slightly worse. ${ }^{47}$ Insofar as this was about what people felt rather than how they actually were, it was some comfort to the Government to know that despite the adverse circumstances of war most people had positive feelings about their health. And to the extent that such feelings translated into good morale, official policies were helping to produce it. The state of the nation's health, like the standard of its food, was not allowed needlessly to impair the effectiveness of the home front; it may even have been a force for improving that effectiveness. 


\section{Recreation and leisure}

So far, the review of the Government's attempts to 'ease the strain' of war on the home front has concentrated on the necessities of life. While this remained the priority, it came to be accompanied, after a while, by a parallel strategy of promoting popular well-being through recreation and leisure. We have seen how in the early months of the war the official attitude was characterized by an almost puritanical attitude to such things. ${ }^{48}$ The positive steps subsequently made to relax the restrictions on sport and entertainment and even to expand provision in certain areas, testifies to the strengthening recognition in Government circles of the therapeutic value of such activities for a hard-worked, overstrained and war-weary civilian population. Nothing is more indicative of this than the licence given to the $\mathrm{BBC}$ and the cinema industry to provide virtual escape routes from the war and to make the people laugh.

At the BBC the main means of fulfilling this brief was the Forces Programme, set up initially to cater for the taste of the thousands of conscripted young men in barracks and training camps across the country and overseas, but quickly becoming the whole nation's favourite listening. The FP broadcast mainly dance and popular music and variety shows, presented in a relaxed and informal manner. It ran some news, talks and discussions, but in the main it left these areas to the National Programme. The original aim of providing diversion and entertainment for the armed forces never disappeared; but as time went on the value of the service for the nation as a whole came increasingly to be appreciated in official quarters. Entertainment, while appearing merely to entertain, could actually help to make workers more efficient. This was context of the introduction of Music While You Work (MWYW) in mid-1940. Half an hour of seamless dance band music was put out on the Forces Programme three times a day - at mid-morning, mid-afternoon and $10.30 \mathrm{pm}$. Its target audience was factory workers, the theory being that the tedium of repetitive tasks on long shifts could be relieved by a background of cheerful and familiar music. Experiments in the 1930s, mostly in the USA, suggested that the technique could improve productivity, too. Background music was a long way from BBC traditions; it liked to think of all its programmes in terms of the 'attentive listener' even when, as in the case of $M W Y W$, the 
Variety Department was the organizer. However, if it made workers more contented and more productive, as was claimed, it was not to be denied, especially since the BBC was at the time still anxious about its future and therefore looking for ways to please its political masters. The experiment was hugely successful on every count. By 1944, four and a half million workers in over 8,000 factories were hearing $M W Y W$. This was spectacular enough, but the unexpected bonus was that the broadcasts were equally popular with listeners at home and in the Forces. While the BBC never seriously claimed that MWYW measurably increased factory production - after all, it went out for only ninety minutes in every twenty-four hours - it could feel sure the programme positively served the cause of popular morale. Workers, service personnel and listeners at home were united, metaphorically speaking, as they tuned in, knowing that at the same time their family members in distant places were doing likewise. For the managers of the BBC there was also the clear and comforting evidence that the Government was interested and impressed. ${ }^{49}$ Beyond the specific function of Music While You Work the barriers to the idea of 'background music' more generally were removed. The resistance to indiscriminate 'on tap' listening that was strong in the Music Department, was in effect bypassed by the creation of the Forces Programme, whose raison d'être it was to supply it. As a result, serious music did not have to make way for the burgeoning upstart, since it was able to continue as before on the Home Service; and the proportion of total output devoted to dance music, which had been at 5 per cent in 1938, increased to 10 per cent by $1942 .^{50}$

On the variety side, the war years saw a substantial blossoming of diversion and laughter production over the airwaves. Some managers in the BBC were in fact itching to expand this aspect of broadcasting even before the Ministry of Information's injunction to cheer the nation up. In August 1940 the Listener Research Department produced a policy statement based on its soundings of the audience, in which it stressed the importance for audience morale of programmes that provided colour, stimulation and laughter. 'It is not too much to claim', it said, 'that such programmes are a valuable part of the cement which binds the nation together as a community. ${ }^{,} 1$ This document followed a survey conducted by Mass-Observation in May 1940, which showed that even at this 
time of worrying developments in the war in France, listeners wanted lighthearted, cheerful programmes. A majority thought the BBC was 'too serious' and there was a desire, especially among respondents in social classes $\mathrm{C}$ and $\mathrm{D}$, for a greater proportion of variety programmes in the output. Typical responses: 'Well, you don't want to be too serious in wartime', 'we want something cheerful in this crisis', 'Oh I like them [variety shows]. I think they cheer us up quite a bit .... You get so low and depressed these days and then that comes along, and we feel better afterwards, for a little while. ${ }^{52}$ The signs were clear: if the BBC wanted to fulfil its entertainment brief, it had to make changes. It did so by shifting somewhat from its tradition of top-down programming. The demand was met with an increase in the air time for variety programmes, mostly on the Forces Programme, making it a working principle that there should be at least one substantial variety programme every night.

The FP in effect quickly became the preferred service of 60 per cent of the listeners as a whole and no less than 90 per cent of the sixteen to twenty age group. ${ }^{53}$ On the BBC's programmes more generally, a listener survey made in April and May 1944 revealed the popularity of its dance music and variety shows. On the FP the top ten programmes were either of dance music or comedy. Even on the Home Service, three of the top ten fell into these categories and the most popular programme of all was a comedy show, Tommy Handley's zany and irreverent ITMA. ${ }^{54}$ If it did not know it already, the $\mathrm{BBC}$ discovered that its previous programming had not given the audience what it really wanted and that it was now more in tune with this newly-desirable idea of what a national broadcasting service ought to be offering in time of war. And the 'wireless' thereby became more truly a means of escape from the stresses of the war. The policy even had a payoff in terms of external propaganda. As recalled by a former monitor of German broadcasts, working at the listening station at Caversham, there was utter perplexity in the Axis countries about what they were hearing when they tuned in to the BBC's domestic programmes; for more often than not, what they got was the sound of upbeat dance music or, even more puzzling at a time when they presumed everyone in Britain was in a state of fright about the prospect of invasion, gales of wild audience laughter at the crazy comedy of ITMA or Hi Gang! ${ }^{155}$ What they were in fact hearing was the sound of the BBC, working 
at the Government's behest, successfully doing its bit to sustain the morale of the people. As the war developed, it became increasingly clear just how important this particular means of escape was. Chapter 2 discussed how the war was a manufactory of human loneliness. For the millions of people affected, radio was simply able to ease the burden. How significant it was in this therapeutic role depended on individual circumstances. That it was helping people to laugh at their fears and difficulties seems borne out by the hilarious welcome given weekly to ITMA's Jack Train announcing himself as 'Funf, your favourite spy', (to which Tommy Handley would respond: 'It may be Funf for you, but it's not much funf for me'), and to Mona Lott's lugubriously delivered catch-phrase, 'It's being so cheerful as keeps me going'. Radio's very ubiquity, its presence - if only as mere background - to people's lives at home and at work, suggests that what it offered was needed and that in meeting the need the BBC was helping people to 'carry on'.

The cinema was, of course, no stranger to the business of providing escape routes: thrillers, costume dramas, romances and comedies were its stock in trade. While there is no evidence that the Government took an active interest in this aspect of film making, it had an interest in keeping down the huge cost of making propaganda films by allowing the commercial enterprises, whose skills they used, to remain economically viable - and for this they needed to continue making films that were 'good box office'. And the very fact that it allowed some of the scarce resources needed by film makers to be used to make such apparently frivolous products in these serious times, suggests that it knew well enough what it was doing. A delegate of the Bristol and West England branch of the Cinematograph Exhibitors' Association, H. F. Wren, a man with his ear close to the ground, wrote as early as January 1940: 'People want something that will take them out of themselves and help them overcome the depression of the blackout ... They do not want heavy drama - they have all the drama they need in the news these days. ${ }^{56}$ Just so: common sense dictated, quite as much as objective calculation, that entertainment was good for people, good for morale. In time, the Ministry of Information followed where Mr Wren led - at least, once Brendan Bracken had become Minister - and the official climate for films of pure escapism became more helpful. 
Given the green light to continue to do what they did best, producers set to make the 'dream palace' live up to its sobriquet, in the somewhat unfamiliar service of war. Alongside the films dutifully produced in fulfilment of the propaganda brief handed to them by the Ministry of Information, therefore, came a stream of pure escapism. This stream, moreover, was a golden one as far as the box office was concerned. The most popular British film of 1943 was Gainsborough Films' costume melodrama, The Man in Grey, and another of the genre, The Wicked Lady (1945), was one of the British industry's biggest box office successes in the whole of the 1940s. Meanwhile, The Crazy Gang, George Formby, Gracie Fields, Will Hay, Tommy Trinder, Frank Randle and other stars of comedy filled the cinemas with audiences only too content to forget the war for an hour or so and drink the medicine of laughter. And if proof were needed that escapist cinema was fulfilling a vital human need, the most popular of all films shown in the war (which happened to be from Hollywood) was Gone With the Wind - a war film of sorts, of course, but an exercise in escapism, none the less. It should be added that some films, such as Korda's Lady Hamilton (1940), Carol Reed's The Young Mr Pitt (1941), and Thorold Dickinson's The Prime Minister (1941), contrived both to meet the demand for escapist costume drama and at the same time drive home the message that through heroic figures like Nelson, Pitt, and Disraeli, Britain had long been the upholder of liberty and democracy against European tyrants.

The practicalities of getting to the cinema were naturally made more difficult by bombing alerts, the blackout and curtailed bus services; and the domestic circumstances that forced many peopleespecially service wives with young children - to settle for the radio, remained little-changed throughout the war. Despite this, the figures for cinema attendance show no decline. In the 1943 Wartime Social Survey it was revealed that 32 per cent of the population went at least once a week. The cinema industry, then, like the radio - although without radio's advantage of a half-captive audience - was succeeding in reaching a significant proportion of the people. And like the radio, it willingly shouldered a large part of the burden of entertaining the nation. Its financial reward was high, but this takes nothing away from the value this role had for the important objective of easing the strain of war. 
As if putting its money where its mouth was, the Government itself went indirectly into the entertainment business. It did this by funding two organizations, the Council for the Encouragement of Music and the Arts (CEMA), and the Entertainments National Services Association (ENSA). CEMA aimed to help fill the spaces in the cultural landscape caused by the dislocation and disruption of war: the breakup of orchestras, choirs, repertory companies, and the like under the impact of evacuation, bombing and conscription. ENSA concentrated - though not exclusively - on light entertainment for service personnel and factory workers. Together these two organizations took entertainment and diversion to the people all over the country, often in their places of work or training. In 1944, its peak year, CEMA put on 6,140 recitals and concerts; and over the course of the war ENSA staged over two million concerts, more than five hundred of them full-scale symphony concerts. ${ }^{57}$ It did not stop at concerts, however. The cultural range was in fact very wide: George Formby and Gracie Fields as well as Sadler's Wells Ballet, the London Philharmonic Orchestra, the Royal Opera, the sculpture of Henry Moore, the paintings of Graham Sutherland and John Piper, to mention only some of the better-known of the hundreds of musicians, dancers, actors, variety performers and artists whose work was sponsored by CEMA and ENSA. There were undoubtedly occasions when there was a serious mismatch between the promoters' offerings and the tastes of the half-captive audiences in canteens and hostels; and some of the variety acts, especially, compared badly with what people were used to from the cinema and radio. However, the effect, such as it is possible to gauge it, was generally positive for its intended purposes. Overall, there was an acknowledged deficit of entertainment and cultural diversion, compared with the years before the war - as for most aspects of life, this was a time of austerity. Anything, therefore, that reduced the deficit and mitigated the austerity - easing the strain - was a contribution to the wider aim of sustaining the morale of the people.

Partly in response to the Government's promptings, publicly assisted entertainment also became the concern of local authorities. The 'Holidays at Home' initiative was aimed to provide some compensation to war-weary citizens, deprived by the necessities of war of the annual battery-recharge of a stay abroad or, more typically, of a week or two at a British seaside resort - by the summer of 1940 
mostly given over to barbed wire, tanktraps and pillboxes. Summer entertainments in parks were, of course, a long-established institution in most cities; what the scheme did was simply to expand and extend the idea. The London County Council, for instance, spent $£ 25,000$ on summer entertainments in 1943, twice the budget for the previous year. This funded not only the usual bandstand concerts, but in addition a circus, which moved from venue to venue during the summer, a regatta on the Thames at Hackney, numerous evening dances - a choice of thirteen every evening - and stagings of musical comedy, opera and even ballet. ${ }^{58}$

None of this quite made up for the change of scene and pleasures of the seaside. But since these were in effect unavailable - in their pre-war form, at least - it was a case of making the best of it. The efforts of local councils were generally well-supported by the public, so one might reasonably infer that their effect was positive, that they helped in a small way to lessen the stress and boredom of war, particularly in the summers of 1941 to 1944.

\section{Some essential inessentials}

The apparatus of controls, as has been shown, established a rather low threshold for the classification of consumer goods as 'inessential'. By any rational process, tobacco, alcohol, cosmetics and flowers would have little chance of avoiding such a classification. Yet all escaped it - and the explanation is not really so irrational, after all.

Distilling was effectively stopped, except for a small amount of whisky produced entirely for export. But beer production was allowed to continue as before - at reduced strength, to be sure - but enough to allow an increase in consumption of 25 per cent during the war. It was never rationed, moreover, except by price, for it didn't benefit from price control and was subjected to several increases in excise duty. There were occasional supply problems related to bombing and the more urgent transport needs of the military, but on whole it was everywhere freely available throughout the war. With increased consumption came a rise in drunkenness. For a government anxious to ensure the maximum efficiency of the workforce, this should have been cause for concern. But magistrates, presumably acting on their own initiative, invariably treated cases brought before them with considerable leniency, as if recognizing 
that in such stressful times the resort to the amnesiac properties of alcohol was perfectly understandable and scarcely to be penalized. In any case, the toleration of high levels of alcohol consumption came from the top, by example, if not by writ. Churchill himself consumed prodigious quantities of wine and spirits and was virtually a stranger to tea and coffee. 'To Mr Churchill a meal without wine is not a meal at all', his Private Secretary recalled. ${ }^{59}$ And round the corner in Whitehall, as civil servant Robert Bruce Lockhart recorded in his diary, things were much the same: 'I am drinking far too much - like most people in Whitehall these days ... The ministers are no better; Dalton has a strong head, drinks hard and has a particular liking for brandy. Brendan [Bracken] is rarely completely sober after $11 \mathrm{pm}$, and even Eden takes a man's full share in the evening. War's effect on nerves, I suppose. ${ }^{60}$

Tobacco, likewise, had the favoured treatment of never being rationed. The price rose, too, and there were interruptions to supplies - for civilians, if not for the forces. But cigarettes were generally to be had everywhere, at all times, for the Government decided that supplies should be maintained at the level of demand. And just as people drank more, they smoked more, too. Nerves again? For many people a strong cup of tea would do the trick, but for millions, smoking was what enabled them to carry on. One of the striking incidental features of photographs and documentary and newsreel films of the time is the ever-present cigarette in the hands of workers and office staff, off-duty service personnel, diplomats and politicians - male and female alike.

For both alcohol and tobacco, official indulgence of popular demand was not brought about simply by the needs of the Treasury - although the Chancellor was doubtless well-pleased with the receipts. The logic lay in the familiar connection between good cheer and good morale - something manufacturers of 'inessential' products like alcoholic drinks and cigarettes understood well and relentlessly promoted in their advertisements. If civilians were cheered by being able to drink and smoke more or less at will, they would be more efficient and committed participants on the home front. So sure was the Government of this presumption, it never seriously considered departing from it. Exactly the same psychological logic lay behind the decision to ease the application of the Limitation of Supplies Order to the music industry: a small supply of gramophone 
records and needles was made available to the ordinary civilian, and the mental sustenance of favourites heard at will was thereby retained.

In the case of cosmetics the arguments for keeping production going were stronger still. For not only was the appearance of wives and sweethearts judged important to the morale of their servicemen partners; it was equally essential to the morale of women in their various home front roles. If servicemen coming home on leave found their loved ones' appearance as attractive as before, they would return to their own duties in good heart. If women doing their patriotic duty in, say, the inherently unfeminine world of munitions could continue to be able to obtain their favourite aids to beauty, then their morale, too, would be more likely to survive the change. Since both groups were self-evidently crucial to winning the war, it was equally obvious that the small cost in the resources entailed was more than justified. Official acknowledgement of this is discernible in the special allowances of high-grade make-up given to women munitions workers from August 1942, Bevin's exemption of the most highly skilled hairdressers from conscription into war work, also in 1942, and the decision late in 1943 to allow a small increase in the supply of cosmetics for sale. And so, although supplies were never enough and the range of what was available was much reduced, the 'beauty industry' kept going and its moraleboosting products had no shortage of customers. Many testified to the therapeutic effect of a hair-styling or of 'putting on a face'. Even the down to earth Nella Last cheered herself up on the day before her younger son Clifford went to join his regiment in September 1939: 'Tonight I looked a bit washed out, so after tea I changed into my gayest frock and made up rather heavily. ${ }^{\prime} 1$

In a move to save transport, the special trains that traditionally took cut flowers from the Isles of Scilly and the West Country to London, were taken off in the autumn of 1942. Desperate traders tried to get round this by using passenger trains instead. Churchill got to hear of it and immediately ordered the restoration of the flower trains. ${ }^{62}$ Once again, an apparently indefensible indulgence; and once again, a shrewd appreciation of how small things can have large effects. The Prime Minister made sure that the weary citizens of the battered capital got their flowers; and who knows how much the true value of this outweighed the cost of letting it happen? 


\section{Notes}

1 T. H. O'Brien, Civil Defence (HMSO, 1955), p. 526.

2 M-O, File Reports 501 (22 November 1940) and 508 (29 November 1940).

3 M-O, File Report 811, 4 August 1941.

4 O'Brien, Civil Defence, p. 392.

5 West Ham Council had refused to build street shelters when instructed to do so by the Government in 1937-39, insisting that since there would be no war, it was a waste of money. Pressed by the Government, it finally agreed to build the shelters but on condition that the Government pay the full cost. The matter was still unresolved when the Blitz began. See L. Mosley, Backs to the Wall: London Under Fire 1939-45 (Weidenfeld \& Nicholson, 1971), p. 128.

6 O'Brien, Civil Defence, p. 547.

7 R. Titmuss, Problems of Social Policy (HMSO, 1950), p. 245.

8 Ibid., p. 259.

9 Ibid., p. 286.

10 Ibid., p. 348.

11 O’Brien, Civil Defence, p. 384.

12 J. Leutze (ed.), The London Observer: the Journal of General Raymond E. Lee 1940-41 (Hutchinson, 1972), p. 78.

13 Home Intelligence Weekly Report, 12 September 1940, INF/292.

14 M-O, File Report 408, 'Human Adjustments to Air Raids'. The Government tackled the matter of sleep disturbance by issuing earplugs. The public response was apathetic, however. According to Tom Harrisson, 90 per cent of people wanted 'to listen to possible death'. Listening seemed to be an important part of peace of mind: 'With them things in, you'd never know if you was copping it or you wasn't.' T. Harrisson, Living Through the Blitz (Collins, 1976), pp. 108-9.

15 O’Brien, Civil Defence, pp. 654-5.

16 See W. Hancock and M. Gowing, British War Economy (HMSO, 1949), pp. 47-52.

17 See CAB 16/157, Sub Committee on Food Supply in Time of War, Reports, F.S. 13; Report of Sub-Committee on Rationing, 5 October 1936; MAF 72/ 5998 Rationing, 4 January 1937; Board of Trade, Report of the Food (Defence Plans) Department for 1937 (HMSO, 1938), pp. 10, 25-6.

18 For further discussion of food policy, see E. F. Nash, 'Wartime Control of Food and Agricultural Prices', in D. N. Chester (ed.), Lessons of the War Economy (Cambridge University Press, 1951).

19 R. J. Hammond, Food, vol. 1: The Growth of Policy (HMSO, 1951), pp. 99-100.

20 Ibid., p. 104.

21 Ibid., p. 400.

22 H. I. Report, 'Inequality of sacrifice', 25 March 1942, INF 1/292.

23 The average weekly earnings of men aged 21 and over in July 1942 was $£ 5$ 11s, HMSO, Facts and Figures, p. 233.

24 When a meal-tokens scheme was shown to the Trades Union Congress Advisory Committee early in 1943, the response was uncooperative. Hammond, Food, vol. 1, p. 292. 
25 D. Reynolds, Rich Relations: the American Occupation of Britain, 19421945 (Harper Collins, 1995), p. 149.

26 M-O, File Report 1155.

27 M-O, File Report 1224; G. H. Gallup, The Gallup International Public Opinion Polls: Great Britain, 1937-1964, vol. 1 (Random House, 1976), p. 87.

28 Lord Woolton, Memoirs (Cassell, 1959), p. 263.

29 Ibid., p. 228.

30 See A. Milward, War, Economy and Society (Allen Lane, 1977), pp. 105-6.

31 Forced savings were compulsory deductions from pay, to be invested at the employee's choice in a Post Office savings account, a trade union or a Friendly Society and repayable after the war.

32 HMSO, Fighting with Figures (HMSO, 1995), p. 234.

33 Ibid., p. 233. Between 1938 and 1945 the increase in wage rates in all industries over the increase in the cost-of-living was 17.5 per cent.

34 Ibid., p. 236.

35 (Pensioners) Titmuss, Problems of Social Policy, p. 516; (soldiers' wives) S. Ferguson and H. Fitzgerald, Studies in the Social Services (HMSO, 1954), p. 22.

36 Petrol rationing, for example, was a great deprivation for the better-off but had practically no effect on the working and lower middle classes.

37 J. L. Hodson, The Land and the Sea (Gollancz, 1945), p. 238.

38 H. M. D. Parker, Manpower (HMSO, 1957), p. 425.

39 Ibid., pp. 412-15.

40 Ibid., pp. 417-19.

41 P. Inman, Labour in the Munitions Industries (HMSO, 1957), p. 252.

42 Ibid., p. 239.

43 Speech at a food production exhibition at Watford. Reported in The Times, 15 September 1941.

44 In 1988 the historian Peter Hennessy tried living for a week on the rations allowed at the end of the war. He found the diet very monotonous and lost two pounds in weight, but admitted that he rarely felt hungry during the experiment. See P. Hennessy, Never Again: Britain 1945-1951 (Jonathan Cape, 1992), pp. 49-50.

45 M-O, File Report 532.

46 Harrisson, Living Through the Blitz, p. 282.

47 Summary report of the Ministry of Health for the year ended 31 March 1943, Parliamentary Papers 1942-43, vol. 4, Cmd. 6468, 1943, pp. 7-8.

48 See Chapter 3.

49 See, for example, Letter from R. Lloyd Roberts, Ministry of Labour, 18 November 1943, cited in A. Briggs, The War of Words (Oxford University Press, 1970), p. 576.

50 D. Cardiff and P. Scannell, 'Radio in World War II', U203 Popular Culture, Block 2, Unit 8 (Open University Press, 1981), p. 35.

51 Listener Research, 'Broadcasting Policy', 27 August 1940, BBC WAC R9/15/1.

52 M-O, File Report 149, 28 May 1940.

53 LR/433, 2 December 1941, BBC WAC R/9/5; LR/556, 13 January 1942, R9/ $9 / 6$. 
54 (Full title It's That Man Again). See A. Briggs, The War of Words, vol. 3 of his History of Broadcasting in the United Kingdom (Oxford University Press, 1970), p. 595.

55 'What Did You Do in the War Auntie?' Produced for BBC 1 by Jeremy Bennett, May 1995.

56 'Open Forum', Daily Film Renter, 1 January 1940. Cited in J. Chapman, 'British Cinema and "the People's War"', in N. Hayes and J. Hill (eds), Millions Like Us? British Culture and the Second World War (Liverpool University Press, 1999), p. 41.

57 See N. Hayes, 'More Than Music While You Eat? Factory and Hostel Concerts, "Good Culture" and the Workers', in Hayes and Hill (eds), Millions Like Us? (Liverpool University Press, 1999), p. 223.

58 P. Ziegler, London at War: 1939-1945 (Alfred A. Knopf, 1995), pp. 246-7; N. Longmate, How We Lived Then (Hutchinson, 1971), p. 254.

59 Cited in P. Fussell, Wartime (Oxford University Press, 1989), p. 98.

60 K. Young (ed.), The Diaries of Sir Robert Bruce Lockhart (Macmillan, 2 vols, 1973-80, vol. 2) p. 130.

61 R. Broad and S. Fleming (eds), Nella Last's War, p. 15.

62 See A. J. P. Taylor, English History 1914-45 (Oxford University Press, 1965), p. 669. 